\title{
Investigating Exports Performance between Malaysia and OIC Member Countries from 1997-2012
}

\author{
Nor'Aznin Abu Bakar ${ }^{1}$, Irwan Shah Zainal Abidin ${ }^{1} \&$ Muhammad Haseeb ${ }^{1}$ \\ ${ }^{1}$ School of Economics, Banking and Finance (SEFB), College of Business (COB), Universiti Utara Malaysia, \\ Sintok, Kedah, Malaysia \\ Correspondence: Muhammad Haseeb, School of Economics, Banking and Finance (SEFB), College of Business \\ (COB), Universiti Utara Malaysia, 06010 Sintok, Kedah, Malaysia. Tel: 60-17-295-7409. E-mail \\ scholar_economist@yahoo.co.uk
}

Received: December 31, 2014 Accepted: January 26, 2015 Online Published: March 16, 2015

doi:10.5539/ass.v11n7p11

URL: http://dx.doi.org/10.5539/ass.v11n7p11

\begin{abstract}
The purpose of this study is to examine the impact of macroeconomic factors such as GDP, CPI, TRGDP and ER on exports between Malaysia and other OIC countries using a panel data for the period of 1997-2012. The panel unit root tests have been applied to confirm the stationarity and level of integration. The overall unit root tests (Dickey \& Fuller, 1979; Im, Pesaran, \& Shin, 2003; Levin, Lin, \& James Chu, 2002) result shows that all the variables are stationary at level and become non-stationary after taking first difference. The Kao cointegration test results approved the cointegration among the panel of proposed countries. After confirm the stationarity level and cointegration FMOLS test is employed to analyze whether a long run relationship between variables exist. The results obtained show that only GDP, TRGDP and ER have significant effect on exports. In examining the short-run relationships among variables, a panel ECM is the applied and it is observed that only ER and TRGDP have positive effect on exports. Results from this study can be used as guidance for policy makers on exports where government can give more attention on both ER and TRGDP to influence exports in the short run.
\end{abstract}

Keywords: exports, FMOLS, OIC, Malaysia

\section{Introduction}

There are several researcher developed the definition of international trade but the most common is "The buying and selling of goods and services across national borders is known as international trade". International trades have huge contribution in the world economy. International trade plays an important role in the development process in Malaysia particularly in transforming the economy from a low income to upper-middle income category. Since three decades the United States of America, The European Union (EU) and Japan were Malaysia's major trading partners. Nevertheless, Malaysian importing and exporting trends have been changed after the world economic and financial crises in 2008 and 2009. The Malaysian main trends of imports and exports are changes towards new and non-traditional markets such as (MITI, 2010). Under the New Economic Model (NEM), the Malaysian government has embarked on a new strategy to shift its trade dependency on the traditional markets and exploring new markets for exports and imports. One of the markets being targeted is the Middle Eastern countries. In addition, exports relationship between Malaysia and other OIC countries becoming more relevant especially after the world economic and financial crisis in 2008 and 2009. Therefore it is vital to study and analyze the on-going Malaysia-OIC trade relationship in this context. Figure1.1 shows the Malaysian trade with other OIC countries.

The purpose of this study is to examine the impact of macroeconomic factors i.e. GDP, CPI, TRGDP and ER on exports between Malaysia and other OIC countries using a panel data from 1997 - 2012. The results of this study will reveal whether all variables have impact on exports between Malaysia and other OIC countries, therefore appropriate policies can be implemented by the government. According to author's best knowledge this is one of the pioneer study which probe the relationship between Malaysian exports and other macroeconomic variables of Malaysia and other OIC members countries. Furthermore, applying recently developed Fully Modify OLS for long run and short run relationship and recent time period from 1997-2012 are also be the contribution of this study. 


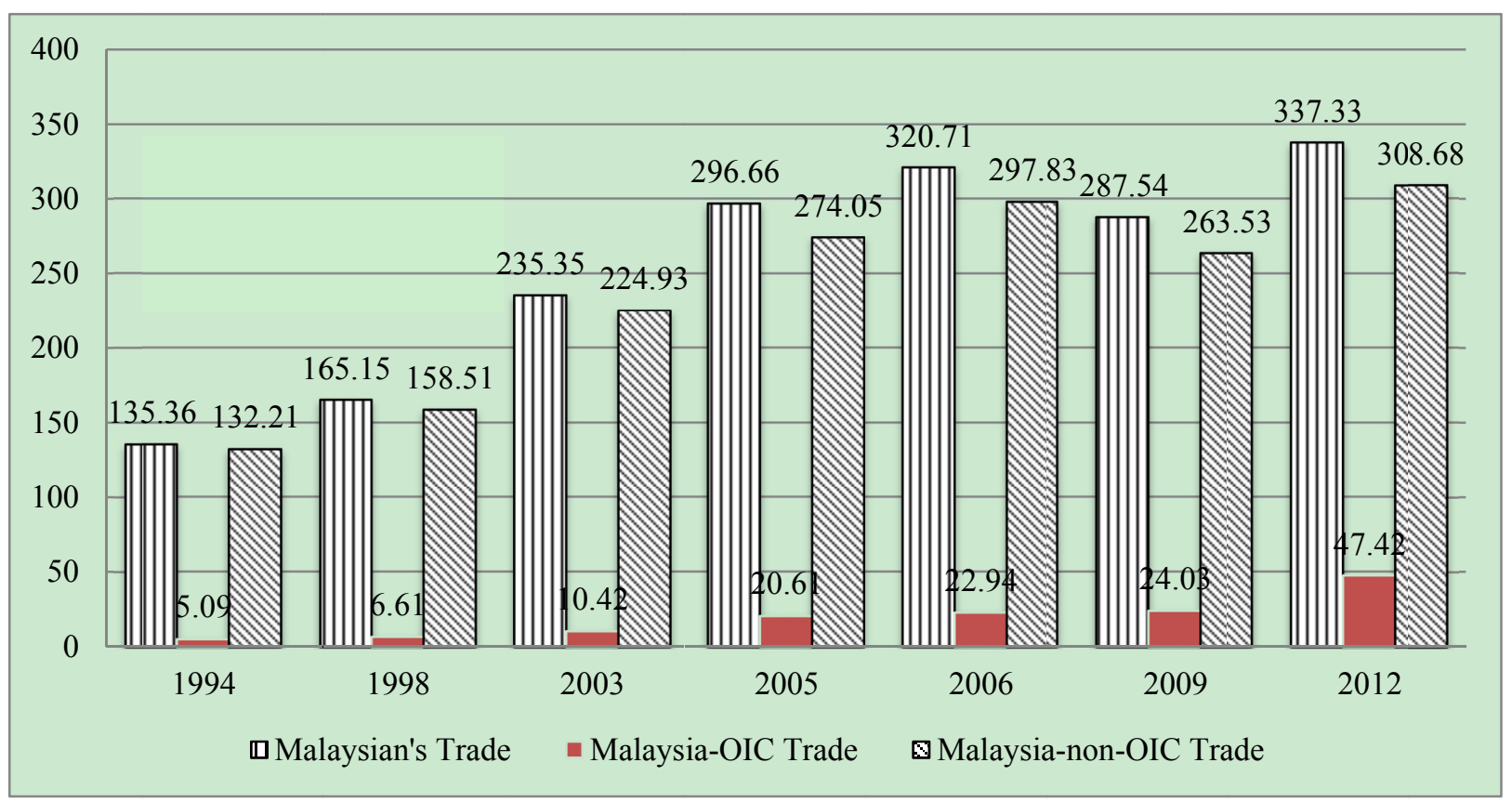

Figure 1. Malaysia-OIC Trade for the Year 1998, 2003, 2005, 2006, 2009, and 2012

Source: http://www.carsicm.ir/icmroot/public/Statistics/OIC-View.htm. Retrieved on 29 September 2013.

The rest of the paper is outlined as follows. Section 2 provides the review of pervious literature based on international trade, exports and intra-OIC exports. Section 3 discusses theoretical framework followed by empirical data used and methodology in section 4. Empirical results are presented in section 5. Section 6 concludes.

\section{Literature Review}

Exports plays very important role in the economic development. Numerous studies such as Ekholm, Torstensson, and Torstensson (1996); Bendjilali (2000); Al-Atrash and Yousef (2000); Nugent and Miniesy (2006) Ghani (2007), ABU-HUSSIN (2010) and Haseeb, Hariyatie Hartani, Abu Bakar, Azam, and Hassan (2014) have pay attention on the Middle East and North African (MENA) region, which embrace the immensity of OIC members. Moreover, K. Hassan (2002) and Gundogdu (2009) focused on South Asian Association for Regional Cooperation (SAARC). The proposed studies on MENA and OIC countries illustrate that trade dimensions for countries in these regions are small, and categorize the small intensity of trade related services, a lack of trade related information, the subsistence of tariff and non-tariff obstacle, and vacant of trade structures as barriers to regional cooperation and trade. These countries' unbalanced and contracted exports bases also offer slight encouragement to prospective regional partners in term of ascertain long-term economic associations.

The proposed studies on MENA and OIC countries illustrate that trade dimensions for countries in these regions are small, and categorize the small intensity of trade related services, a lack of trade related information, the subsistence of tariff and non-tariff obstacle, and vacant of trade structures as barriers to regional cooperation and trade. These countries' unbalanced and contracted exports bases also offer slight encouragement to prospective regional partners in term of ascertain long-term economic associations. The study of Haseeb et al. (2014) investigates the relationship between exports and economic growth of Malaysia during 1971-2013. The results of Autoregressive Distributed Lag Model (ARDL) explore that exports have statistically positive and significant effects on the economic growth of Malaysia.

Additionally, these OIC members' countries reliance on non-OIC members' countries for imports and exports. Ekholm et al. (1996) use cross-sectional data for 11- developing countries and 13-industrial countries and argue that impending for trade growth inside the MENA regions, even with the more peaceful countries, and the European Union (EU) is small. Bendjilali (2000) explore the situation of intra-trade between OIC member countries by using gravity model. The results of the study shows that trade of OIC countries positively exaggerated by the size of their economies, the degree of IDB trade financing and their mutual involvement in regional integration schemes. While trade of OIC countries negatively affected by communication and 
transportation costs as proxy for the distance factor which constitutes a significant barrier to trade among OIC countries.

Ghani (2007) used Tobit procedure to explore the effects of trade among members of Arab Maghreb Union (AMU) and the members of Gulf Cooperation Council (GCC). The results show that effects are negative, which is patently unusual from estimates for other free trade agreements (FTA). Utilizing cross-country regressions, M. K. Hassan, Sanchez, and Hussain (2010) demonstrate that trade openness has a positive and significant impact on growth for many countries, the effect has been smaller.

ABU-HUSSIN (2010) also explore the scope of economic integration between five members of the Arab States (LAS) and include five of their major partners; the results show that the LAS economic alliance has not been effectual in cause trade growth, representing a collapse of its members to instate integrative procedures. Meanwhile, Hassan (2001) examines the role of exports towards development in SAARC countries. He argue that SAARC countries need trade rectification to boost trade among them because the size of trade between SAARC countries is small as compare to trade with non-SAARC countries. K. Hassan (2002) investigate Malaysia- OIC trade using gravity model approach from the period 1980-2006. The empirical results of this study claim that GDP of Malaysia and OIC countries, exchange rate, foreign direct investment (FDI) and distance are the major determinants of exports in Malaysia.

\section{Analytical Framework and Data Source}

There are number of studies that estimate export equations for OIC. However, since there have been many economic changes in the world generally, and in OIC, in particular, a re-examination, using the latest data available, and employing the current econometric techniques, is essential. Therefore, the purpose of this section is to develop the following model of exports in which all the methodological issues concerning the exports equation estimation will be taken into consideration.

\subsection{Model Specification}

We specify the following equation to analyze the effects macroeconomic factors on exports between Malaysia and other OIC countries;

$$
\begin{aligned}
& \ln \text { Export }_{i t}=\alpha_{i}+\beta_{1} \ln G D P_{i t}+\beta_{2} \ln G D P_{j t}+\beta_{3} \ln C P I_{i t}+\beta_{4} \ln C P I_{j t}+\beta_{5} \ln E R_{i t}+ \\
& \beta_{6} \ln E R_{j t}+\beta_{7} \ln T R G D P_{i t}+\beta_{8} \ln T R G D P_{j t}+\varepsilon_{t}
\end{aligned}
$$

where

$\begin{array}{ll}\text { Export }_{\mathrm{it}} & =\text { Exports from Malaysia to other OIC countries } \\ \mathrm{GDP}_{\mathrm{it}} & =\text { Gross Domestic Product of Malaysia } \\ \mathrm{GDP}_{\mathrm{jj}} & =\text { Gross Domestic Product of other OIC countries } \\ \mathrm{CPI}_{\mathrm{it}} & =\text { Consumer Price Index of Malaysia } \\ \mathrm{CPI}_{\mathrm{jj}} & =\text { Consumer Price Index of other OIC countries } \\ \mathrm{ER}_{\mathrm{it}} & =\text { Real Exchange rate of Malaysia } \\ \mathrm{ER}_{\mathrm{jj}} & =\text { Real Exchange rate of other OIC countries } \\ \mathrm{TRGDP}_{\mathrm{ii}} & =\text { Trade contribution in the GDP of Malaysia } \\ \mathrm{TRGDP}_{\mathrm{jj}} & =\text { Trade contribution in the GDP of other OIC countries } \\ \mathrm{B} & =\text { Coefficient } \\ \varepsilon_{\mathrm{t}} & =\text { Error term }\end{array}$

\subsection{Data Sources}

The annual time series data of Malaysia and other 54-OIC countries has been selected from various sources. The data of real Gross Domestic Product, Consumer Price Index, Trade contribution in the GDP and real exchange rate of Malaysia and other OIC member countries from the year 1997 to 2012 was taken from World Development Indicator (WDI). Whereas, data of Malaysian exports with other OIC countries are taken from the Direction of Trade Statistics, CD-ROM database and website of International Monetary Fund (IMF).

\subsection{Estimation Method}

There are several econometric techniques for panel data analysis. This study will apply Fully Modify OLS proposed by Pedroni (2001)to confirm the long run relationship between selected macroeconomic variables of 
Malaysia and other OIC countries. To investigate the long run and short relationship overall six different steps have been applied. First, to confirm the stationarity and order of integration panel unit root test such as Maddala and $\mathrm{Wu}$ (1999); Levin et al. (2002) and Im et al. (2003) are utilized. There is assumption for FMOLS that all variables must be stationary at level I (0) or at first difference I (1). For the time series data it is possible to analysis the mixture of level I (0) and first difference I ( 0 ) variables by applying Autoregressive Distributed Lag Model (ARDL) but unfortunately there is none econometric technique has been developed to analysis the mixture variables in panel data. Second, assume that all the variables are stationary at level I (0) or at first difference I (1). The panel cointegration approach proposed by Kao (1999) will applied to examine the residual based cointegration among proposed variables. Third, after confirm the order of stationarity and cointegration the FMOLS technique has utilized to investigate the long run relationship between the proposed variables. It is observed that the long run relationship results from FMOLS some time show spurious results. To confirm the results are not spurious fourth step to used unit root tests of the residuals of FMOLS model without trend and intercept formation. Fifth, explore the short run relationship by applied panel Error Correction Model (panel ECM).

\subsection{Panel Unit Root Test}

The available literature such as Phillips and Perron (1988) and Dickey and Fuller (1979) provide the unit root test for the individual and time series data. These tests are suffering with several problems especially have low power against the alternative of stationarity of the series, especially if the sample size is small. The panel unit root test such as Im et al. (2003); Levin et al. (2002) and Maddala and Wu (1999) have numerous advantages. For example, theses tests are provide large no of point data, increase the value of degree of freedom and reduce multicollinearity between the two regressors. Panel unit root can written as follow:

$$
\Delta X_{i t}=\alpha_{i}+\beta_{i} X_{i, t-1}+\sum_{k=1}^{n_{i}} \rho_{i j} \Delta X_{i, t-j}+\varepsilon_{i t} \quad \mathrm{i}=1, \ldots \ldots, \mathrm{N}, \mathrm{t}=1, \ldots \ldots, \mathrm{T}
$$

where

$\begin{array}{lll}\Delta & = & \text { First difference } \\ \mathrm{X}_{\mathrm{it}} & = & \text { current panel of Malaysian series } \\ \mathrm{t} & = & \text { Time period } \\ \mathrm{n}_{\mathrm{i}} & = & \text { No of lags } \\ \varepsilon_{\mathrm{it}} & = & \text { Distributed random variables }\end{array}$

\subsection{Panel Cointegration Approach}

After examine the unit root test if the results shows that all the variables are stationary at same level Kao (1999) panel cointegration will applied. The model for panel cointegration can be written as follow:

$$
X_{i t}=\alpha_{i}+Y_{i t} \beta+\omega_{i t}
$$

where

$\begin{array}{ll}\mathrm{i} & =1 \ldots \mathrm{N} \\ \mathrm{t} & =1 \ldots . \mathrm{T} \\ \varepsilon_{\mathrm{i}} & =\text { Represent the individual constant term } \\ \mathrm{B} & =\text { Stand for slop parameter } \\ \omega_{\mathrm{i}} & =\text { Shows stationary distribution } \\ \mathrm{X}_{\mathrm{it}} \text { and } \mathrm{Y}_{\mathrm{it}} & =\text { Presented integrated process of order I (1) for all i }\end{array}$

Kao (1999) drives two types (Dickey \& Fuller, 1979; Phillips \& Perron, 1988) of panel cointegration tests. Both test can be written as follow

and

$$
\varpi_{i t}=\rho \varpi_{i t-1}+V_{i t}
$$

$$
\varpi_{i t}=\rho \varpi_{i t-1}+\sum_{j=1}^{\rho} \phi_{j} \Delta \varpi_{i t-j}+V_{i t}
$$

where $\varpi_{i t-1}$ obtained from Equation (2). For null hypothesis $H_{O}: \rho=1$ and alternative hypothesis $H_{1}: \rho \angle 1$ is used. 


\subsection{Fully Modify OLS}

As mentioned earlier to explore the long run relationship it is important to confirm the stationarity level and cointegration. At this stage study assume that all the variables are stationary and there is cointegration the long run relationship test FMOLS proposed by Pedroni (2001) has been applied. Let Equation (2), can obtain the between-dimension Equation (5)

$$
\bar{\sigma}_{G F M}=N^{-1} \sum_{i=1}^{N}\left[\sum_{t=1}^{T}\left(X_{i t}-X^{\prime}{ }_{i}\right)^{2}\right]^{-1}\left[\sum_{t=1}^{T}\left(X_{i t}-X^{\prime}{ }_{i}\right) Y^{\prime}{ }_{i t}-T r{ }^{\prime}{ }_{i}\right]
$$

where $\varpi_{G F M}=N^{-1} \sum_{i=1}^{N} \varpi_{F M} \cdot \varpi_{F M i}$ is the FMOLS estimator for individual variable.

\subsection{Panel Error Correction Model (Panel ECM)}

Furthermore, a panel ECM were applied to analyze the short-run relationship among variables. A panel ECM model is specified as follows;

$$
\begin{aligned}
& \Delta \ln \text { Export }_{i t}=\mu_{i}+\sum_{j=1}^{11} \delta_{j} D_{j i t}+\sum_{j=1}^{p} \varphi_{1 j} \Delta \ln G D P_{i t-j}+\sum_{j=0}^{p} \phi_{2 j} \Delta \ln G D P_{j t-j}+\sum_{j-1}^{p} \phi_{3 j} \Delta \ln C P I_{i t-j} \\
& +\sum_{j-0}^{p} \phi_{4 j} \Delta \ln C P I_{j t-j}+\sum_{j-0}^{p} \phi_{5 j} \Delta \ln E R_{i t-j}+\sum_{j-0}^{p} \phi_{6 j} \Delta \ln E R_{j t-j}+\sum_{j-0}^{p} \phi_{7 j} \Delta \ln T R G D P_{i t-j} \\
& +\sum_{j-0}^{p} \phi_{8 j} \Delta \ln T R G D P_{j t-j}+\lambda \varepsilon_{i t-1}
\end{aligned}
$$

\section{Empirical Results}

\subsection{Panel Unit Root Results}

The panel unit root test results are presented in Table1. The results based on various (Dickey \& Fuller, 1979; Im

\begin{tabular}{|c|c|c|c|c|c|}
\hline Panel A & Level & First Difference & Panel B: & Level & First Difference \\
\hline$L N C P I_{i t}$ & $0.02 *$ & & $L N C P I_{i t}$ & 1.00 & $0.00 *$ \\
\hline$L N C P I_{i t}$ & 0.99 & $0.01 *$ & $L N C P I_{i t}$ & 1.00 & $0.00 *$ \\
\hline$L N E R_{i t}$ & 1.00 & $1.00 *$ & $L N E R_{i t}$ & $0.01 *$ & \\
\hline$L N C P I_{i t}$ & 0.08 & $0.00 *$ & $L N C P I_{i t}$ & 0.72 & $0.00 *$ \\
\hline$L N E X P O R T_{i t}$ & 1.00 & $0.00 *$ & $L N E X P O R T_{i t}$ & 1.00 & $0.00 *$ \\
\hline$L N G D P_{i t}$ & 1.00 & $0.00 *$ & $L N G D P_{i t}$ & 1.00 & $0.00 *$ \\
\hline$L N G D P_{i t}$ & 0.40 & $0.00 *$ & $L N G D P_{i t}$ & 1.00 & $0.00 *$ \\
\hline$L N T R G D P_{i t}$ & 1.00 & $0.00 *$ & $L N T R G D P_{i t}$ & 1.00 & $0.00^{*}$ \\
\hline LNTRGDP $P_{i t}$ & $0.03 *$ & & LNTRGDP $P_{i t}$ & 0.37 & $0.00 *$ \\
\hline Panel C: & & & Panel D: & & \\
\hline$L N C P I_{i t}$ & 1.00 & $0.00 *$ & $L N C P I_{i t}$ & 1.00 & $0.00 *$ \\
\hline$L N C P I_{i t}$ & 0.99 & $0.00 *$ & $L N C P I_{i t}$ & 0.12 & $0.00^{*}$ \\
\hline$L N E R_{i t}$ & $0.02 *$ & & $L N E R_{i t}$ & 1.00 & $0.00 *$ \\
\hline$L N C P I_{i t}$ & 0.62 & $0.00 *$ & $L N C P I_{i t}$ & 0.73 & $0.00 *$ \\
\hline$L N E X P O R T_{i t}$ & 1.00 & $0.00 *$ & $L N E X P O R T_{i t}$ & 1.00 & $0.00 *$ \\
\hline$L N G D P_{i t}$ & 1.00 & $0.00 *$ & $L N G D P_{i t}$ & 1.00 & $0.00 *$ \\
\hline$L N G D P_{i t}$ & 1.00 & $0.00 *$ & $L N G D P_{i t}$ & 1.00 & $0.00 *$ \\
\hline$L N T R G D P_{i t}$ & 1.00 & $0.00 *$ & $L N T R G D P_{i t}$ & 1.00 & $0.00 *$ \\
\hline$L N T R G D P_{i t}$ & 1.00 & $0.00 *$ & $L N T R G D P_{i t}$ & 1.00 & $0.00 *$ \\
\hline
\end{tabular}
et al., 2003; Levin et al., 2002; Phillips \& Perron, 1988) tests are suggested that all the variables are stationary at level but after taking first difference all variables become non-stationary and significant at $5 \%$ critical value.

Table 1. Unit Root Test Results

Note: panel A consist on (Levin et al., 2002); panel B consist on (Im et al., 2003); Panel C consist on (Dickey \& Fuller, 1979), panel C consist on (Phillips \& Perron, 1988); *denoted significant at 1 percent critical value

The unit root test results presented in the above Table are based on different tests. The decision of stationarity based on the majority decision. According to overall results all the variables are stationary at first difference. There is no evidence of mixture of stationary at level I (0) and I(1) or stationary at second difference I (2). Consequently, these results are allowed to proceed further for Kao cointegration test and FMOLS long run relationship test. 


\subsection{Panel Cointegration Test Results}

To investigate the panel cointegration Kao (1999) test has been applied. The results of panel Kao cointegration are reported in Table2. The results show that Malaysian exports and other macroeconomic variables of Malaysia and other 54-OIC countries are cointegrated within the panel of proposed countries.

Table 2. Cointegration Test Result based on Kao (1999)

\begin{tabular}{ccc}
\hline Test & $t$-Statistic & P-Value \\
\hline ADF & -5.766596 & 0.0000 \\
\hline
\end{tabular}

According to given p-value there is significant cointegration between proposed variables.

\subsection{FMOLS Results}

Based on the previous results it is confirmed that all variables; export, $\mathrm{GDP}_{i}, \mathrm{GDP}_{j}, \mathrm{PCGDP}_{i}, \mathrm{CPI}_{i}, \mathrm{CPI}_{j}, \mathrm{ER}_{i}$, $\mathrm{ER}_{j}, \mathrm{TRGDP}_{i}, \mathrm{TRGDP}_{j}$ are cointegrated. We then proceed to analyze whether there exist a long run relationship between variables using a panel cointegration technique. The results of FMOLS are reported in Table 3.

Table 3. FMOLS Test

\begin{tabular}{ccccc}
\hline Variables & Coefficient & Std. Error & $t$-Value & $P$-Value \\
\hline LNGDP $_{i}$ & 19.48493 & 6.647995 & -2.930948 & $0.0039^{*}$ \\
LNGDP $_{j}$ & 1.451818 & 2.395304 & 0.606110 & 0.5453 \\
LNTRGDP $_{i}$ & 9.378233 & 3.113720 & 3.011907 & $0.0030^{*}$ \\
LNTRGDP & 0.290620 & 0.809078 & 0.359199 & 0.7199 \\
LNCPI $_{i}$ & 12.19262 & 7.918930 & 1.539681 & 0.1256 \\
LNCPI $_{j}$ & 3.054546 & 1.860290 & 1.641973 & 0.1026 \\
LNER $_{i}$ & 13.28256 & 2.662923 & 4.987962 & $0.0000^{*}$ \\
LNER $_{j}$ & -0.529118 & 0.976545 & -0.541827 & 0.5887 \\
\hline
\end{tabular}

*denote significant at 5 percent

The results presented in the Table3 variables such as GDPi, TRGDPi and ERi has significant positive effect on exports.

\subsection{FMOLS Residual Test}

Table 4. Results of FMOLS Residual

\begin{tabular}{lllll}
\hline \multirow{2}{*}{ Test } & LEVEL & & \multicolumn{2}{c}{ FIRST DIFFERENCE } \\
\cline { 2 - 5 } (Levin et al., 2002) & t-statistics & p-values & t-statistic & p-value \\
(Dickey \& Fuller, 1979) & -6.563 & 000 & -12.094 & 000 \\
(Phillips \& Perron, 1988) & 96.940 & 000 & 162.22 & 000 \\
\hline
\end{tabular}

The results show that long run results are not spurious.

\subsection{Panel ECM Model}

A panel ECM is then applied to examine the short-run relationships among all variables. Results of panel ECM are reported in Table 5.

Table 5. Panel ECM (dependent variable $\triangle$ LNEXPORT)

\begin{tabular}{ccccc}
\hline Variables & Coef & Std. Err & $t$-Value & $P$-Value \\
\hline$\Delta$ LNGDP $_{i}$ & 4.832153 & 3.473523 & 1.391139 & 0.1660 \\
$\Delta$ LNGDP $_{j}$ & 0.204775 & 1.722519 & 0.118881 & 0.9055 \\
$\Delta$ LNTRGDP $_{i}$ & 7.108162 & 1.760562 & 4.037439 & $0.0001^{*}$ \\
$\Delta$ LNTRGDP $j$ & 0.337664 & 0.590847 & 0.571492 & 0.5684 \\
$\Delta$ LNCPI $_{i}$ & -5.71345 & 5.485602 & -1.041535 & 0.2991 \\
$\Delta$ LNCPI $_{j}$ & 0.924390 & 1.316117 & 0.702362 & 0.4834 \\
$\Delta$ LNER $_{i}$ & 12.51135 & 1.908178 & 6.556703 & $0.0000^{*}$ \\
$\Delta$ LNER $_{i}$ & -0.23278 & 0.732809 & -0.317654 & 0.7511 \\
ECM $(-1)^{C}$ & -0.441938 & 0.057155 & -7.732232 & $0.0000^{*}$ \\
\end{tabular}


The short run results are presented in Table 4 shows that $1 \%$ disequilibrium increase exports by 0.44 percent so it takes 2.27 time periods to restore the equilibrium. From the short run variables it is observed that there are ER and TRGDP positively causing exports in short run.

\section{Conclusions}

This paper examines the role of macroeconomic factor in influencing exports between Malaysia and other OIC countries during the 1997-2012. First the panel unit root tests such as Levin, Lin \& Chu (2002), Im, Pesaran\& Shin (2003), ADF Fisher Chi Square and (Phillips \& Perron, 1988) Chi Square was applied. The results indicate that all the variables are stationary at first difference. Furthermore, Koa (1999) test confirm the cointegration among proposed variables. Study found that all variables are cointegrated within the panel of 55-OIC countries. In addition the FMOLS results confirmed that a long run relationship exists between all variables. By using a panel ECM model, it is revealed that ER and TRGDP positively influencing exports in the short run. Therefore in order to continue and increase competition on exports, it is crucial for Malaysia to formulate policies regarding to exchange rate and trade.

\section{References}

Ab Rahman, A. B., \& Abu-Hussin, M. F. B. (2009). GCC economic integration challenge and opportunity for Malaysian economy. Journal of International Social Research, 2(9).

Abidin, I. S. Z., Bakar, N. A. A., \& Haseeb, M. (2014). An Empirical Analysis of Exports between Malaysia and TPP Member Countries: Evidence from a Panel Cointegration (FMOLS) Model. Modern Applied Science, $8(6), 238$.

Abidin, I. S. Z., Bakar, N. A. A., \& Sahlan, R. (2013). The Determinants of Exports between Malaysia and the OIC Member Countries: A Gravity Model Approach. Procedia Economics and Finance, 5, 12-19. http://dx.doi.org/10.1016/S2212-5671(13)00004-X

Abidin, I. S. Z., Jantan, M. D., \& Satar, N. M. Trade Linkages between Malaysia and the Oic Member Countries: An Empirical Analysis Based on Gravity Model.

ABU-HUSSIN, M. (2010). Exploring international trade between Malaysia and GCC countries: Empirical analysis on trends, developments and challenges. Durham University.

Al-Atrash, H., \& Yousef, T. (2000). Intra-Arab trade: Is it too little?

Bendjilali, B. (2000). An Intra-trade Econometric Model for OIC Member Countries: A Cross-country Analysis: Islamic Research and Training Institute, Islamic Development Bank.

Dao, M. Q. (2014). Exports, imports, government consumption and economic growth in upper-middle income countries. Progress in Development Studies, 14(2), 197-204. http://dx.doi.org/10.1177/1464993413517791

Devadason, E. S., Baharumshah, A. Z., \& Subramaniam, T. (2014). Leveraging trade opportunities with non-traditional partners: the Malaysia-GCC perspective. The Pacific Review, 27(1), 97-122. http://dx.doi.org/10.1080/09512748.2013.848377

Dickey, D. A., \& Fuller, W. A. (1979). Distribution of the estimators for autoregressive time series with a unit root. Journal of the American statistical association, 74(366a), 427-431. http://dx.doi.org/10.1080/ 01621459.1979.10482531

Ekholm, K., Torstensson, J., \& Torstensson, R. (1996). The economics of the Middle East peace process: Are there prospects for trade and growth? The World Economy, 19(5), 555-574. http://dx.doi.org/10.1111/j.14679701.1996.tb00697.x

Engle, R. F., \& Granger, C. W. (1987). Co-integration and error correction: representation, estimation, and testing. Econometrica: journal of the Econometric Society, 251-276. http://dx.doi.org/10.2307/1913236

Ghani, G. M. (2007). Does OIC Membership Reduce Trade? Journal of Economic Cooperation, 28(4), 39-62.

Gundogdu, A. S. (2009). Determinant of Intra-OIC Trade; Policy or Exchange Rate. Journal of Economic Cooperation and Development, 30(3), 1-42.

HASAN, Z. (2011). Sharīah governance in Islamic financial institutions in Malaysia, GCC countries and the UK. Durham University.

Haseeb, M., \& Azam, M. (2015). Energy Consumption, Economic Growth and CO2 Emission Nexus in Pakistan. Asian Journal of Applied Sciences, 8, 27-36. http://dx.doi.org/10.3923/ajaps.2015.27.36

Haseeb, M., Bakar, N. A. A., Azam, M., Hassan, S., \& Hartani, N. H. (2014). The Macroeconomic Impact of 
Defense Expenditure on Economic Growth of Pakistan: An Econometric Approach. Asian Social Science, 10(4), 203. http://dx.doi.org/10.5539/ass.v10n4p203

Haseeb, M., Hariyatie Hartani, N., Abu Bakar, N. A., Azam, M., \& Hassan, S. (2014). Exports, foreign direct investment and economic growth: Empirical evidence from Malaysia (1971-2013). American Journal of Applied Sciences, 11(6), 1010-1015. http://dx.doi.org/10.3844/ajassp.2014.1010.1015

Hassan, K. (2002). An empirical investigation of economic cooperation among the OIC member countries.

Hassan, M. K., \& Islam, F. (2001). Prospect and Problems of a Common Market: An Empirical Examination of the OIC Countries. American Journal of Islamic Social Sciences, 18(4), 19-46.

Hassan, M. K., Sanchez, B. A., \& Hussain, M. E. (2010). Economic Performance of the OIC Countries and the prospect of an Islamic Common Market. Journal of Economic Cooperation and Development, 31(2), 65-121.

Ilias, S. (2008). Islamic finance: overview and policy concerns.

Im, K. S., Pesaran, M. H., \& Shin, Y. (2003). Testing for unit roots in heterogeneous panels. Journal of econometrics, 115(1), 53-74. http://dx.doi.org/10.1016/S0304-4076(03)00092-7

Ismail, N. (2008). Explaining Malaysian Bilateral Trade Using the Gravity Model. The Empirical Economic Letters, 7(8), 811-818.

Kao, C. (1999). Spurious regression and residual-based tests for cointegration in panel data. Journal of econometrics, 90(1), 1-44. http://dx.doi.org/10.1016/S0304-4076(98)00023-2

Laldin, M. A. (2008). Islamic financial system: the Malaysian experience and the way forward. Humanomics, 24(3), 217-238. http://dx.doi.org/10.1108/08288660810899377

Levin, A., Lin, C.-F., \& James Chu, C.-S. (2002). Unit root tests in panel data: asymptotic and finite-sample properties. Journal of econometrics, 108(1), 1-24. http://dx.doi.org/10.1016/S0304-4076(01)00098-7

Maddala, G. S., \& Wu, S. (1999). A comparative study of unit root tests with panel data and a new simple test. Oxford Bulletin of Economics and statistics, 61(S1), 631-652. http://dx.doi.org/10.1111/1468-0084.61.s1.13

MITI. (2009). MITI annual report 2008. Ministry of International Trade and Industry (MMITI), Kuala Lumpur, Malaysia

Nugent, J. B., \& Miniesy, R. S. (2005). Are these shortfalls in MENA trade? If so what are their sources and what should be done about them? Proceedings of the ERF 12th Annual Conference, December 19-21, 2005, Cairo, Egypt.

Pedroni, P. (2001). Fully modified OLS for heterogeneous cointegrated panels. Advances in econometrics, 15, 93-130. http://dx.doi.org/10.1016/S0731-9053(00)15004-2

Phillips, P. C., \& Perron, P. (1988). Testing for a unit root in time series regression. Biometrika, 75(2), 335-346. http://dx.doi.org/10.1093/biomet/75.2.335

Rahman, A. A., Yahya, M. A., \& Nasir, M. H. M. (2010). Islamic norms for stock screening: A comparison between the Kuala Lumpur Stock Exchange Islamic Index and the Dow Jones Islamic Market Index. International Journal of Islamic and Middle Eastern Finance and Management, 3(3), 228-240. http://dx.doi.org/10.1108/17538391011072426

Zeinelabdin, A., \& Ugurel, I. (1998). The Islamic Common Market: Is it economically and politically justifiable? Humanomics, 14(4), 79-117. http://dx.doi.org/10.1108/eb018818

\section{Copyrights}

Copyright for this article is retained by the author(s), with first publication rights granted to the journal.

This is an open-access article distributed under the terms and conditions of the Creative Commons Attribution license (http://creativecommons.org/licenses/by/3.0/). 